\title{
HUBUNGAN PITC ( PROVIDER INITIATED TESTING AND COUNSELING ) OLEH BIDAN KIA/KB DENGAN PENGETAHUAN IBU HAMIL TENTANG PPIA ( PENCEGAHAN PENULARAN HIV DARI IBU KE ANAK ) DI WILAYAH KERJA PUSKESMAS BRATI
}

\author{
Desiliana Puji Andari ${ }^{1}$, Nur Khafidhoh², Ulfah Musdalifah ${ }^{3}$ \\ 1,2,3 Jurusan Kebidanan, Poltekkes Kemenkes Semarang
}

\begin{abstract}
Pregnant women are one of the key populations who have the risk of comparative HIVIAIDS to the fetus it contains. Such as transmission can occur during pregnancy, childbirth, and lactation. In Grobogan district there was always a baby or child with HIV possitive in every year. Therefore, the policy arises that every pregnant woman must be examined by HIV. The examination was named PITC (Provider Initiated Testing and Counseling). PITC colaborated with ANC (Ante Natal Care) in Primary Health Center. The purpose of this study is to know the relationship of PITC (Provider Initiated Testing and Counseling) by Midwife KIA/KB with the knowledge of pregnant women about PPIA in the work area of Brati Primary Health Center. This type of this research is correlative analytic with a cross-sectional approach. The method of this research used questionnaires. The samples in this study around 56 pregnant mothers who tested HIV in Brati Puskesmas. Sampling techniques using Accidental sampling were incidentally met by researchers. And data analysis bivariateused Chi-Square. The results of statistical analysis with Chi-Square get $p$-value of $0.032<0.05$. Ha received that there was a relationship between PITC (Provider Initiated Testing and Counseling) by midwife KIA/KB with the knowledge of pregnant women about PPIA. Based on the results this research is expected to midwife KIA/KB in Brati Primary Health Center more improve the quality of service PITC.Because the PITC given by midwives affects the knowledge of pregnant women.
\end{abstract}

Keywords: PITC, Knowledge, PPIA 


\section{PENDAHULUAN}

Penyebab dari AIDS adalah Human Immuno deficiency Virus (HIV). Penularan HIVIAIDS saat ini tidak hanya sebatas pada pengguna narkoba suntik (penasun), Pekerja Seks Komersil ( PSK ), Laki-laki Seks dengan Laki-laki (LSL), penderita Tuber Colusis (TB) dan heteroseksual.Ibu hamil dengan HIV positif lebih dari $90 \%$ akan menularkan ke bayinya. Baik melalui kehamilan, persalinan maupun menyusui. Ibu dan bayi dengan HIVIAIDS berpeluang menyumbangkan AKI (Angka Kematian Ibu) maupun AKB (Angka Kematian Bayi) yang dapat menentukan derajat kesehatan masyarakat di suatu negara. Kejadian HIVIAIDS pada ibu hamil juga mempersulit capaian dari target Rancangan Pembangunan Jangka Menengah Nasional (RPJMN) 2015-2019 di bidang kesehatan. Penegakan status HIV pada ibu hamil sangat penting dilakukan sedini mungkin untuk mencegah penularan kepada bayinya atau Mother To Child Tranmission (MTCT). Inayatul, K. \& Suyani, 2017

Program/kegiatan pengendalian HIV AIDS yang saat ini dilakukan mencakup 16 kegiatan yang salah satunya adalah Pencegahan Penularan HIV dari Ibu dan Anak (PPIA). Strategi ini diharapkan dapat memberikan harapan bagi anak- anak untuk terlahir bebas dari HIV dari ibu yang terinfeksi HIV. Ada empat strategi pencegahan dalam PPIA yaitu pencegahan penularan terhadap wanita reproduktif, pencegahan kehamilan yang tidak direncanakan pada wanita dengan HIV positif, pencegahan penularan HIV pada ibu hamil positif ke bayinya dan pemberian dukungan psikologis kepada ibu HIV positif beserta keluarganya, Dinas Kesehatan Kabupaten Grobogan. \& SR GF-AIDS Jawa Tengah, 2019

Berdasarkan keadaan diatas, pemerintah membuat PERMENKES Nomor 52 Tahun 2017 tentang "Eliminasi Penularan HIV, Sifilis dan Hepatitis B dari ibu ke anak". Eliminasi tersebut kemudian dikenal dengan istilah triple eliminasi. Dalam rangka upaya eliminasi penularan HIV dari ibu ke anak,perlu dilakukan penanggulangan yang terintegrasi, komprehensif, efektif dan efisien. Target dari program triple eliminasi di tahun 2022 dengan indikator berupa infeksi baru kurang dari 50/100.000 kelahiran hidup.

Pemeriksaan Triple Eliminasi di Kabupaten Grobogan sendiri mulai diwajibkan pada awal tahun 2018, karena pada tahun 2017 ditemukan kasus ibu hamil positif HIV sebanyak 18 kasus dan semuanya menularkan HIV ke bayinya. Hal ini sangat ironis dan riskan sekali. Meskipun pemeriksaan HIV sudah menjadi kewajiban bagi semua ibu hamil namun cakupan ibu hamil di Kabupaten Grobogan yang periksa HIV belum mencapai target $100 \%$ yaitu baru mencapai 65 \%. Berdasarkan Peraturan Daerah Kabupaten Grobogan No.4 tahun 2014 tentang penanggulangan HIV-AIDS, bahwa semua yang beresiko tertular HIV 
harus melakukan pemeriksaan HIV. Mengingat Kabupaten Grobogan menduduki peringkat tertinggi ke 3 se Jawa Tengah setelah Kota Semarang dan Banyumas.

Pemeriksaan HIV dibedakan menjadi 2 yaitu Voluntary Counseling and Testing ( VCT) dan Provider Initiated Testing and Counseling ( PITC ). VCT adalah suatu tes darah secara sukarela dan dijamin kerahasiaannya dengan informed consent melalui proses konseling yang digunakan untuk memastikan seseorang positif terinfeksi HIV dengan cara mendeteksi antibody HIV di dalam sampel darahnya. Sedangkan PITC adalah petugas kesehatan yang menyarankan untuk tes HIV pada pasien yang berikutnya dilakukan konseling. Provider dalam hal ini bisa bidan atau perawat ataupun dokter yang menyediakan layanan. Tahapan pelaksanaan PITC dibagi menjadi 3 yaitu, informasi pra tes, tes HIV, dan konseling pasca tes. Inayatul, K. \& Suyani,2017

PITC merupakan pelayanan kesehatan yang sangat strategis dalam program PPIA. PITC merupakan layanan yang terintegrasi di sarana kesehatan yang melibatkan lebih dari satu pelayan kesehatan. PITC pada ibu hamil diberikan pada saat ibu hamil melakukan pemeriksaan ANC terpadu di Puskesmas. Penegakan status HIV sedini mungkin pada pemeriksaan PITC sangat penting untuk mencegah penularan HIV kepada bayi. Selain itu di dalam tahapan pelaksanaan PITC terdapat konseling yang diharapkan menambah pengetahuan ibu hamil tentang penularan HIV dari ibu ke bayi/anak yang dikandungnya. Penegakan diagnosa sedini mungkin melalui PITC dapat meningkatkan program PPIA sehingga pemberian terapi ARV ibu hamil dapat diberikan lebih awal.

Faktor yang mempengaruhi ibu hamil dalam periksa HIV tidak hanya dipengaruhi peran bidan tetapi tingkat pendidikan ibu juga berpengaruh. Penelitian lain juga menerangkan bahwa ada pengaruh promosi kesehatan tentang HIVIAIDS terhadap peningkatan pengetahuan remaja. (Takainginan, C. at all. 2014)

Hasil studi pendahuluan yang dilakukan di Puskesmas Brati didapatkan prosentase ibu hamil yang periksa HIV pada tahun 2018 sebesar $49,1 \%$ hal ini telah mengalami peningkatan dibandingkan tahun 2017 yang hanya $5,9 \%$. Meskipun mengalami peningkatan di tahun 2018, namun capaian Puskesmas Brati masih paling rendah dibanding dengan Puskesmas lain yaitu Puskesmas Grobogan $78 \%$ dan Puskesmas Penawangan 89 \%. Sedangkan capaian di tahun 2019 sampai bulan Agustus adalah 60\%. Hal ini menunjukkan peningkatan yang cukup bagus. Selama Januari - Agustus 2019 Puskesmas Brati telah menemukan kasus ibu hamil dengan HIV positif sebanyak 3 orang. Penemuan ini dikatakan banyak dibandingkan puskesmas lain di Kawedanan Grobogan 
yang tidak ditemukan kasus ibu hamil positif HIV.

\section{METODOLOGI PENELITIAN}

Jenis penelitian ini adalah penelitian analitik korelatif, rancangan penelitian yang digunakan adalah cross sectional. Pend. Variabel yang digunakan pada penelitian ini adalah variabel bebas dan terikat, dimana variabel bebas adalah variabel yang mempengaruhi variabel terikat.

Populasi dalam penelitian ini adalah semua ibu hamil yang datang ke Puskesmas Brati untuk melakukan pemeriksaan HIV. Pengambilan sampel penelitian ini menggunakan teknik accidental sampling. Jumlah sampel dalam penelitian ini adalah 56 ibu hamil. Waktu penelitian dilakukan pada bulan Maret 2020 di wilayah kerja Puskesmas Brati Kabupaten Grobogan.

Alat ukur dalam penelitian ini adalah lembar checklist mengenai kegiatan PITC yang dilakukan oleh bidan $\mathrm{KIA} / \mathrm{KB}$ dan kuesioner untuk mengetahui tingkat pengetahuan ibu hamil Teknik pengolahan data yang digunakan peneliti adalah editing, coding, entry, tabulating, dan cleaning.

Analisa yang digunakan adalah univariat dan bivariat. Analisa univariat menggunakan distribusi frekuensi. Sedangkan bivariat menggunakan uji statistik Chi Square..

\section{HASIL PENELITIAN DAN BAHASAN}

Analisis Univariat

$\begin{array}{lrl}\text { Tabel } 1 & \text { Distribusi frekuensi } \\ \text { responden }\end{array}$

Distribusi frekuensi karakteristik responden berdasarkan umur, pendidikan, pekerjaan, dan gravida di Puskesmas Brati tahun 2020

\begin{tabular}{ccc}
\hline Karakteristik & $\mathrm{f}$ & Persen \\
\hline Umur : & & \\
$(20-35$ th $)$ & 50 & 89,3 \\
$(<20 \&>35$ th $)$ & 6 & 10,7 \\
Total & 56 & 100 \\
\hline Pendidikan : & & \\
Dasar & 41 & 73,2 \\
Menengah & 12 & 21,4 \\
Atas & 3 & 5,4 \\
Total & 56 & 100 \\
\hline Pekerjaan : & & \\
Bekerja & 15 & 26,8 \\
Tidak bekerja & 41 & 73,2 \\
Total & 56 & 100 \\
\hline Gravida : & & \\
Primigravida & 21 & 37,5 \\
Sekundigravida & 24 & 42,9 \\
Multigravida & 11 & 19,6 \\
Total & 56 & 100 \\
\hline
\end{tabular}

Tabel diatas menunjukkan bahwa distribusi umur responden mayoritas 2035 tahun yaitu pada usia reproduktif sehat 50 responden ( $89,3 \%$ ). Dari tingkat pendidikan sebagian besar berpendidikan dasar (SD dan SMP) 41 responden (73,2 \%). Distribusi kelompok pekerjaan mayoritas ibu hamil tidak bekerja yaitu sejumlah 41 responden (73,2 \%). Dan dilihat dari distribusi responden menurut gravida/ kehamilan hampir separuh responden adalah sekundigravida 24 responden ( $42,9 \%$ ). 
Tabel 2 Distribusi frekuensi kategori kegiatan PITC oleh bidan KIA/KB tahun 2020

\begin{tabular}{cccc}
\hline No & PITC & f & Presentase \\
\hline 1 & Tidak sesuai & 30 & 53,6 \\
\hline 2 & Sesuai & 26 & 46,4 \\
\hline & Jumlah & 56 & 100 \\
\hline
\end{tabular}

Pada tabel diatas didapatkan data bahwa PITC yang dilakukan oleh bidan KIA/KB sesbagian besar sesuai dengan SOP yang ada yaitu 26 responden (46,4\%) dan yang tidak sesuai SOP sebanyak 30 responden $\quad(53,6 \quad \%) \quad$ sehingga berdasarkan tabel diatas dapat disimpulkan bahwa bidan KIA/KB dalam melakukan PITC belum sesuai standar SOP.

Tabel 3 Distribusi Frekuensi Pengetahuan Ibu Hamil tentang PPIA tahun 2020.

\begin{tabular}{clcc}
\hline No & Kriteria & $\mathrm{f}$ & Presentase \\
\hline 1 & Kurang & 18 & 32,1 \\
\hline 2 & Cukup & 16 & 28,6 \\
\hline 3 & Baik & 22 & 39,3 \\
\hline & Jumlah & 56 & 100 \\
\hline
\end{tabular}

Distribusi frekuensi pengetahuan ibu hamil pada tabel 3 diperoleh hasil bahwa dari 56 responden terdapat 22 responden $(39,3 \%)$ dengan pengetahuan yang baik, 16 responden $(28,6 \%)$ berpengetahuan cukup dan 18 responden $(32,1 \%)$ dengan pengetahuan kurang.

\section{Pembahasan}

1. PITC oleh bidan $\mathrm{KIA} / \mathrm{KB}$

Berdasarkan hasil penelitian yang dilakukan pada bulan Maret 2020 di Puskesmas Brati Kabupaten Grobogan dengan responden ibu hamil sejumlah 56 orang didapatkan hasil bahwa PITC yang dilakukan oleh bidan KIA/KB sebagian besar 30 responden (53,6\%) tidak sesuai dengan SOP yang ada. Hal ini terlihat pada distribusi frekuensi jawaban responden. Terutama pada bagian konseling pra tes, penyampaian hasil dan konseling pasca tes.

Pemberian informasi pra tes HIV oleh bidan $\mathrm{KIA} / \mathrm{KB}$ belum bisa sepenuhnya diberikan. Hal ini didukung dengan hasil tanya jawab terhadap responden yang tidak dilakukan konseling pra tes sebanyak 16 responden (28,6\%). Pentingnya pemberian informasi atau konseling pra pemeriksaan HIV bagi ibu hamil meliputi resiko penularan HIV kepada bayi yang dikandungnya, manfaat diagnosis HIV dini bagi bayi yang akan dilahirkan, dan pengurangan risiko penularan HIV dari ibu ke ke janin dengan pemberian terapi ARB. Kementerian Kesehatan Republik Indonesia

Proses PITC seharusnya dilakukan secara menyeluruh sesuai tahap-tahap dalam SOP. Akan tetapi pelaksanaanya pada Puskesmas Brati masih ada beberapa tahap yang tidak dilakukan oleh bidan. Sehingga kesiapan seorang konselor dalam pelaksanaan pemeriksan 
HIV masih perlu ditingkatkan pada fasilitas kesehatan tingkat pertama (Triana \& Suparmi. 2018).

Peneliti melakukan observasi dan wawancara kepada bidan mengenai alasan bidan $\mathrm{KIA} / \mathrm{KB}$ tidak melakukan PITC sesuai standar SOP adalah karena keterbatasan petugas/bidan $\mathrm{KIA} / \mathrm{KB}$ yang jaga/piket pada saat itu, kerbatasan waktu yaitu banyaknya ibu hamil yang periksa dan tes HIV. Terkendalanya pelaksanaan PITC disebabkan beberapa hambatan seperti keterbatasan waktu dan SDM dan lainnya. (Ernawati, N. dkk. 2018)

\section{Pengetahuan ibu hamil tentang PPIA}

Hasil analisa univariat terhadap variabel pengetahuan ibu hamil tentang PPIA dapat diketahui bahwa dari 56 ibu hamil terdapat 18 ibu hamil (32,1\%) dalam kategori kurang, 16 ibu hamil $(28,6 \%)$ dalam kategori cukup dan 22 ibu hamil $(39,3 \%)$ dalam kategori baik. Berdasarkan hasil tersebut dapat disimpulkan bahwa pengetahuan ibu hamil tentang PPIA di Puskesmas Brati dalam kategori baik. Sebagian besar ibu hamil juga memiliki pengetahuan baik tentang PMTCT yaitu sebanyak 30 responden $(44,1 \%)$ di puskesmas Prambanan (Inayatul, K. \& Suyani.2017).

Pengetahuan ibu hamil tentang PPIA pada penelitian ini paling banyak pada kategori baik, itu artinya sebagian besar ibu hamil bisa menjawab dengan benar $76 \%-100 \%$ dari 24 item pertanyaan pada kuesioner tentang pengetahuan PPIA.

Pengalaman sebagai sumber pengetahuan adalah suatu cara untuk memperoleh kebenaran pengetahuan dengan cara mengulang kembali pengetahuan yang diperoleh dalam memecahkan masalah yang dihadapi masa lalu (Notoadmodjo, S. 2011). Sebagian besar responden dalam kategori sekundigravida ini artinya responden mempunyai peluang lebih untuk berpengetahuan baik karena sudah berpengalaman pada kehamilan sebelumnya. Maka ada hubungan yang bermakna antara paritas dengan pengetahuan ibu hamil tentang PMTCT di Puskesmas Sleman Yogyakarta dengan nilai $p$ value 0,002 Anisa Nurmasari. 2015 Hubungan PITC oleh bidan KIA/KB dengan pengetahuan ibu hamil tentang PPIA

Hasil cross tabulasi antara variabel PITC oleh bidan KIA/KB dengan pengetahuan ibu hamil tentang PPIA menunjukkan hasil uji statistic Chi-Square diperoleh nilai p.value 0.032 (p.value < $0,05)$ yang berarti $\mathrm{Ha}$ diterima, ada hubungan antara PITC oleh bidan KIA/KB dengan pengetahuan ibu hamil tentang PPIA. Sumber informasi dapat mempengaruhi pengetahuan ibu hamil tentang PMTCT dengan nilai $\mathrm{p}$ value $=$ 0,001 (Nofa, A. et all. 2017).

Pengetahuan adalah suatu proses mengingat dan mengenal kembali obyek yang telah dipelajari melalui panca indera 
pada suatu bidang tertentu. Sehingga faktor orang yang memberi informasi juga mempengaruhi pengetahuan ibu hamil tentang PPIA. (Aprilia, N. \& Rafika. S) Petugas kesehatan khususnya bidan harus aktif dalam kegiatan konseling, karena tenaga kesehatan yang terdekat dengan ibu hamil adalah bidan.

Faktor dari mana sumber informasi diperoleh para responden akan mempengaruhi pengetahuan ibu hamil tentang PPIA. Informasi yang tidak lengkap membuat seseorang tidak tahu atau berpengetahuan kurang, namun sebaliknya informasi yang sesuai dan lengkap akan membuat pengetahuan seseorang bertambah baik. (Aprilia, N. \& Rafika. S. 2017).

Konseling yang ada di dalam PITC bertujuan memberikan bantuan bagi pengembangan dan pemahaman klien terhadap permasalahan kesehatan. Mengeksplorasi segala kemampuan atau kelemahan (bio-psiko-sosial-spiritual) yang dimiliki klien untuk menghadapi permasalahan kesehatannya. Layanan konseling bisa diartikan memberikan pengetahuan kesehatan yang bermanfaat bagi klien dalam memelihara dan mengembangkan keseluruhan pribadi yang dimilikinya (pengetahuan,sikap dan perilaku).( Priyanto. 2012)

Pengetahuan ibu hamil akan mengalami peningkatan setelah diberikan konseling tentang PMTCT. (Hendayani, Nurhayati, \& Hanisah.2016.) Hal tersebut membuktikan bahwa pemberian informasi
/ konseling kesehatan kepada seseorang/ ibu hamil dapat meningkatkan pengetahuan orang tersebut tentang informasi/konseling yang diberikan. Pendidikan kesehatan mempunyai pengaruh yang signifikan terhadap pengetahuan dan perilaku PPIA (Rochmawati. 2016)

Stimulus pada penelitian ini adalah pemberian materi atau informasi oleh bidan KIA/KB pada saat PITC (post test HIV) ibu hamil di Puskesmas Brati. Pada kegiatan PITC yang tidak sesuai standar SOP/ bidan tidak melalukan konseling post testdiperoleh pengetahuan ibu hamil tentang PPIA dalam kategori kurang. Sedangkan kegiatan PITC yang sesuai standar SOP/ bidan melakukan konseling post test diperoleh pengetahuan ibu hamil dalam kategori baik. Sehingga pengetahuan ibu hamil tentang PPIA di Puskesmas Brati dipengaruhi oleh informasi yang diberikan oleh bidan $\mathrm{KIA} / \mathrm{KB}$ pada saat PITC.

\section{KESIMPULAN}

1. Sebagian besar responden berada pada usia produktif sehat 50 responden $(89,2 \%)$, pendidikan responden terbanyak dalam kategori dasar 41 responden $(72,3 \%)$, responden paling banyak tidak bekerja 41 responden $(73,2 \%)$ dan sebagian besar responden dalam kategori sekundigravida 24 responden $(42,9 \%)$. 
2. PITC yang dilakukan oleh bidan $\mathrm{KIA} / \mathrm{KB}$ di Puskesmas Brati tidak sesuai dengan SOP yang ada 30 responden $(53,6 \%)$ dari jumlah total responden 56 ibu hamil.

3. Pengetahuan ibu hamil tentang PPIA yang berada di Puskesmas brati berada pada kategori baik 22 responden $(39,3 \%)$.

4. Ada hubungan antara PITC oleh bidan $\mathrm{KIA} / \mathrm{KB}$ dengan pengetahuan ibu hamil tentang PPIA di Puskesmas Brati dengan nilai $p$ value 0.032

\section{DAFTAR PUSTAKA}

1. Anisa Nurmasari. 2015. Tingkat Pengetahuan Ibu Hamil tentang HIVIAIDS dengan Perilaku Pemeriksaan Test PITC (Provider Initiated Testing and Counseling) di Puskesmas Sleman Yogyakarta.

2. Aprilia, N. \& Rafika. S. 2017. Perbedaan Pengetahuan Ibu Hamil Tentang PPIA Sebelum dan Sesudah Diberi Penyuluhan. AKBID Dharma Husada. Kediri

3. Dinas Kesehatan Kabupaten Grobogan. \& SR GF-AIDS Jawa Tengah, 2019. Modul Pelatihan Tes dan Konseling HIV.

4. Ernawati, N. dkk. 2018. Gambaran Pelaksanaan Tes HIV dengan Pendekatan PITC oleh Bidan di Puskesmas Wilayah Kabupaten Sleman. Poltekkes Kemenkes Yogyakarta

5. Farkhanani, F.T, Baroya, N. \& Wahjudi, W. 2015. Implementasi Pelayanan Tes HIV atas Inisiasi Petugas Kesehatan bagi Ibu Hamil di Puskesmas Pakusari Kabupaten Jember. Universitas Jember.

6. Hendayani, Nurhayati, \& Hanisah.2016. Efektivitas Konseling Terhadap Pengetahuan Ibu Hamil Tendang PMTCT. Laporan Penelitian. Bandung
7. Inayatul, K. \& Suyani.2017. Hubungan Pengetahuan ibu hamil tentang PMTCT dengan pemeriksaan VCT di Puskesmas Prambanan. Universitas Aisyiyah Yogyakarta

8. Kementerian Kesehatan Republik Indonesia. Pedoman Nasional Konseling dan Tes HIV.2014

9. Nofa, A. et all. 2017. Faktor-faktor Yang Berhubungan dengan Pengetahuan Ibu Hamil Tentang PMTCT. STIKES Abdi Nusantara Jakarta.

10. Notoadmodjo, S. 2011. IImu Perilaku Kesehatan.Jakarta : PT. Rineka Cipta

11. Peraturan Daerah Kabupaten Grobogan Nomor 4 Tahun 2014 tentang Penanggulangan HIV dan AIDS.

12. Peraturan Menteri Kesehatan Nomor 52 Tahun 2017 tentang Eliminasi Penularan HIV, Sifilis, dan Hepatitis B dari lbu ke Anak.

13. Priyanto. 2012. Komunikasi dan Konseling. Jakarta : Salemba Medika

14. Rochmawati. 2016. Pengaruh Pendidikan Kesehatan terhadap Pengetahuan dan Perilaku Pencegahan Penularan HIV dari lbu ke anak (PPIA). STIKES Yogyakarta

15. Sariningsih \& Yogisusanti, G. 2015. Pengetahuan Bidan tentang Deteksi Dini HIV AIDS pada Ibu Hamil dengan Implementasi Asuhan Kebidanan di Lahan Praktik. STIKES Immanuel Bandung.

16. Takainginan, C. at all. 2014. Pengaruh Promosi Kesehatan tentang HIVIAID Terhadap Tingkat Pengetahuan Remaja.Poltekes Kemenkes Manado.

17. Triana \& Suparmi. 2018. Analisis Kebijakan program Pengendalian HIVIAIDS dan PIMS di Fasilitas kesehatan Tingkat Pertama di Kabupaten Banyumas. Hasil Penelitian Dosen. Poltekkes Kemenkes Semarang

18. Umar, F. \& Erni. 2017. Faktor yang Berhubungan dengan Penerimaan 
Tes HIV oleh Ibu Hamil. Akbid Graha Ananda Palu. 9 (1).

19. Wawan, A. \& Dewi.M, 2010.

Pengetahuan Sikap dan Perilaku

Manusia. Yogyakarta; Nuha Medika. 